\title{
Effect of changes in cerebral blood flow on proportion of high and low flow tissue in the brain ${ }^{1}$
}

\author{
LINNETTE ILIFF, E. ZILKHA, J. W. D. BULL, \\ G. H. DU BOULAY, V. L. MCALLISTER, JOHN MARSHALL, \\ R. W. ROSS RUSSELL, AND LINDSAY SYMON \\ From the Institute of Neurology and the National Hospital for Nervous Diseases, \\ Queen Square, London
}

SYNOPSIS Regional cerebral blood flow was measured by injection of ${ }^{133}$ Xenon into the internal carotid artery in 11 patients with cerebrovascular disease. All patients were studied under general anaesthesia, first at normocapnia and then at hypocapnia. The 15 minute isotope clearance curves were analysed by computer by two-compartmental analysis and regional changes in flow and the proportions of fast and slow clearing tissue obtained at two levels of arterial $\mathrm{CO}_{2}$ tension. Hypocapnia caused a fall in blood flow which was consistently accompanied by a decrease in the proportion of fast clearing tissue. Regional changes were not significantly different from the hemisphere mean changes. There was no correlation between changes in blood flow through grey matter and the proportion of fast clearing tissue on a hemisphere mean basis, but on regional analysis the data from 10 out of the 11 patients showed that in areas where blood flow through grey matter changed most the proportion of fast clearing tissue changed least and vice versa. A hypothesis has been proposed to explain this phenomenon.

Previous work from this group (Wilkinson et al., 1969), by correlating two-compartmental analysis of isotope clearance curves with anatomical dissection, has shown that in normal brain at normocapnia the proportions of fast and slow clearing tissue beneath a detector correspond to the anatomical proportions of grey and white matter. The same correlation was not attempted at hypocapnia because the anatomical proportion of grey and white matter does not change with alterations in the arterial carbon dioxide tension $\left(\mathrm{PaCO}_{2}\right)$, hence the proportion of fast. and slow clearing tissue was not expected to change.

In the pathological conditions of degenerative brain disease Høedt-Rasmussen and Skinhøj (1966) and Ingvar et al. (1968) have shown a decrease in the proportion of fast clearing tissue (conventionally referred to as weight grey; $\mathrm{Wg}$ ) calculated by two-compartmental analysis of isotope clearance curves. The latter authors also

1 This work was supported by the Medical Research Council. showed that cerebral atrophy demonstrated by pneumoencephalography was associated with a decrease in the fast clearing component. As loss of grey matter was to be expected in these conditions, the hypothesis that the proportion of fast clearing tissue demonstrated by twocompartmental analysis of isotope clearance curves represented grey matter was not disturbed.

Salmon and Timperman (1971), however, measured cerebral blood flow (CBF) in patients with head injury before and after ventriculoatrial shunting. Four of the six patients showed improvement in blood flow which was accompanied by an increase in the proportion of fast clearing tissue. While accepting that long-term decrease in the anatomical proportion of grey matter occurs, it seems extremely unlikely that the proportion of grey matter could increase over a short period of time. Thus, the hypothesis that the proportion of fast and slow clearing tissue determined by two-compartmental analysis of isotope clearance curves represents the anatomical proportion of grey and white matter was 
challenged. To test the hypothesis further we have carried out the present study to see whether the proportion of fast and slow clearing tissue remains constant in the same region of brain on consecutive studies at different levels of blood flow.

\section{METHODS}

Regional CBF was measured at two levels of $\mathrm{PaCO}_{2}$ in 11 patients with ischaemic cerebrovascular disease. The patients had a mean age of 49 years; there were seven males and four females (Table 1). All patients

TABLE 1

DETAILS OF THE 11 PATIENTS IN THE STUDY

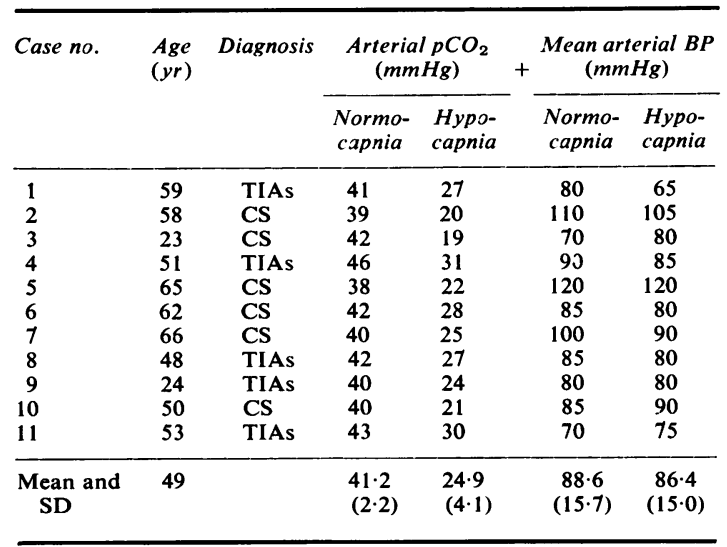

TIAs: transient ischaemic attacks. CS : completed stroke.

were studied under nitrous oxide and oxygen general anaesthesia and immediately before cerebral angiography. The anaesthetic regime has been described in a previous publication (Wilkinson and Browne, 1970). After the injection of about $10 \mathrm{mC}{ }^{133}$ Xenon in about $5 \mathrm{ml}$ saline into the internal carotid artery, regional CBF was measured in 15 areas at two levels of $\mathrm{PaCO}_{2}$. The first study was done at a normal or slightly raised $\mathrm{PaCO}_{2}$. The second study was about 15 minutes after the conclusion of the first, when the counts had returned to background level and the hypocapnic $\mathrm{PaCO}_{2}$ was established and stable at a level of at least $10 \mathrm{mmHg}$ below the normocapnic level. Table 2 shows the levels of $\mathrm{PaCO}_{2}$ for each patient; the mean starting level was $41 \mathrm{mmHg}$ and a fall of between 13-23 $\mathrm{mmHg}$ occurred with hyperventilation. At normocapnia mean arterial blood
TABLE 2

MEAN HEMISPHERE FLOW AND COMPARTMENTAL WEIGHT

\begin{tabular}{|c|c|c|c|c|c|c|}
\hline \multirow[t]{3}{*}{$\begin{array}{l}\text { Case } \\
\text { no. }\end{array}$} & \multicolumn{2}{|c|}{$\begin{array}{l}\text { Arterial } p \mathrm{CO}_{2} \\
(\mathrm{mmHg})\end{array}$} & \multirow{2}{*}{\multicolumn{2}{|c|}{$\begin{array}{c}F g \\
\text { mean value for } \\
\text { hemisphere } \\
(\mathrm{ml} / 100 \mathrm{~g} / \mathrm{min})\end{array}$}} & \multirow{2}{*}{\multicolumn{2}{|c|}{$\begin{array}{c}W g \% \\
\text { mean value for } \\
\text { hemisphere } \\
(\mathrm{ml} / \mathrm{lOJ} \mathrm{g} / \mathrm{min})\end{array}$}} \\
\hline & \multirow{2}{*}{$\begin{array}{l}\text { Normo- } \\
\text { capnia }\end{array}$} & \multirow{2}{*}{$\begin{array}{l}\text { Hyps- } \\
\text { capnia }\end{array}$} & & & & \\
\hline & & & $\begin{array}{l}\text { Normo- } \\
\text { capnia }\end{array}$ & $\begin{array}{l}\text { Hypo- } \\
\text { capnia }\end{array}$ & $\begin{array}{l}\text { Normo- } \\
\text { capnia }\end{array}$ & $\begin{array}{l}\text { Hypo- } \\
\text { capnia }\end{array}$ \\
\hline 1 & 41 & 27 & $84 \cdot 6$ & $49 \cdot 5$ & 55.6 & $41 \cdot 8$ \\
\hline 2 & 39 & 20 & 83.4 & 36.9 & $47 \cdot 1$ & 43.0 \\
\hline 3 & 42 & 19 & 154.7 & $39 \cdot 8$ & $51 \cdot 4$ & 40.9 \\
\hline 4 & 46 & 31 & 143.6 & 50.1 & $45 \cdot 2$ & $41 \cdot 4$ \\
\hline 5 & 38 & 22 & 95.1 & $30 \cdot 5$ & $37 \cdot 1$ & $32 \cdot 2$ \\
\hline 6 & 42 & 28 & $118 \cdot 7$ & $55 \cdot 1$ & 378 & $33 \cdot 1$ \\
\hline 7 & 40 & 25 & 59.9 & 30.6 & $45 \cdot 6$ & $43 \cdot 8$ \\
\hline 8 & 42 & 27 & $44 \cdot 1$ & $29 \cdot 5$ & $34 \cdot 7$ & 30.9 \\
\hline 9 & 40 & 24 & $37 \cdot 4$ & $25 \cdot 5$ & 40.6 & $27 \cdot 3$ \\
\hline 10 & 40 & 21 & 101.6 & $29 \cdot 2$ & $48 \cdot 8$ & $38 \cdot 3$ \\
\hline 11 & 43 & 30 & 76.0 & $38 \cdot 1$ & $44 \cdot 0$ & $40 \cdot 5$ \\
\hline $\begin{array}{l}\text { Mean } \\
\text { and SD }\end{array}$ & $\begin{array}{l}41 \cdot 2 \\
(2 \cdot 2)\end{array}$ & $\begin{array}{l}24 \cdot 9 \\
(4 \cdot 1)\end{array}$ & $\begin{array}{c}90 \cdot 8 \\
(37 \cdot 5)\end{array}$ & $\begin{array}{l}37 \cdot 7 \\
(10 \cdot 0)\end{array}$ & $\begin{array}{l}44 \cdot 3 \\
(6 \cdot 4)\end{array}$ & $\begin{array}{l}37 \cdot 6 \\
(5 \cdot 6)\end{array}$ \\
\hline
\end{tabular}

pressures varied between $70-120 \mathrm{mmHg}$; it did no 5 change more than $15 \mathrm{mmHg}$ when the $\mathrm{PaCO}_{2}$ waș $\mathrm{G}$ lowered. Two-compartmental analysis of each 1 क्रे minute clearance curve was made by computer and the results of the paired studies were compared.

\section{RESULTS}

The cerebral vessels of all 11 patients reacted to the change in arterial $\mathrm{CO}_{2}$ tension. The fall in

\section{TABLE 3}

CHANGES IN FLOW AND COMPARTMENTAL WEIGHT BY REGION

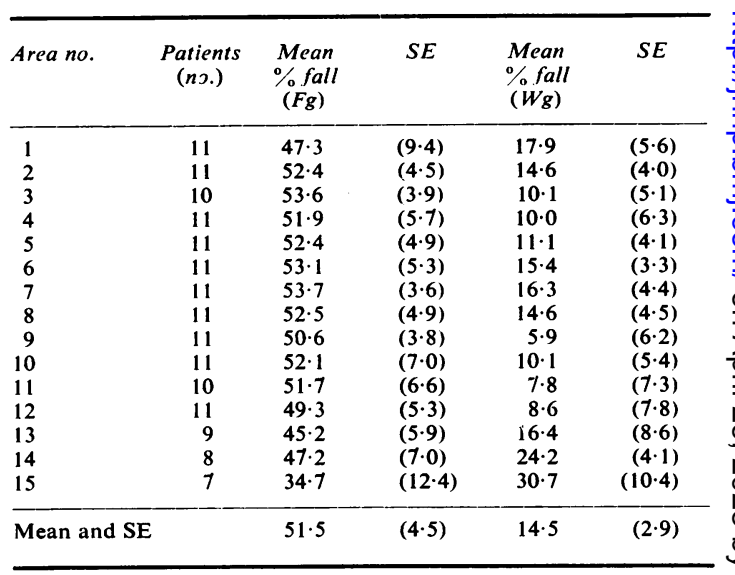


blood flow through the grey matter of the hemisphere (Fg) with hypocapnia was in every case accompanied by a reduction in the proportion of fast clearing tissue $(\mathrm{Wg})$ (Table 2). Examination of the results from each region of the brain showed that regions in which the blood flow at normocapnia was low reacted in the same way as regions in which blood flow was initially normal.
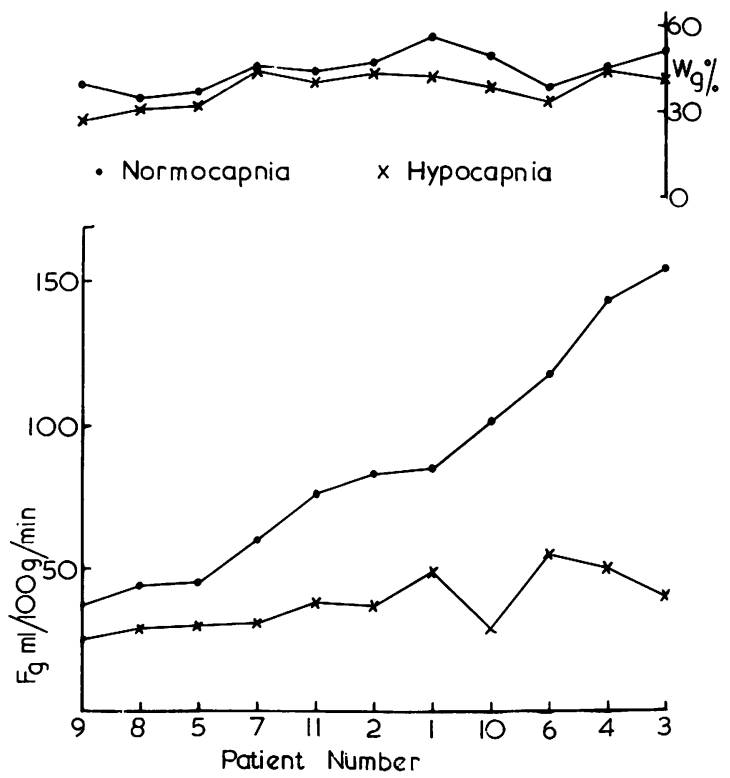

FIG. 1. Mean hemisphere $\mathrm{Fg}$ and $\mathrm{Wg} \%$ at normocapnia (O) and hypocapnia $(\times)$. The patient data have been ranked from left to right according to the level of Fg at normocapnia.

In Table 3 the reduction in regional values for $\mathrm{Fg}$ and $\mathrm{Wg}$ have been expressed as a percentage of the initial value at normocapnia. Regional changes were fairly uniform; in no case did a regional change differ significantly from the change in the mean hemisphere value.

Attention was next directed to the question as to whether the degree of change in $\mathrm{Fg}$ and $\mathrm{Wg}$ for the hemisphere were correlated. In Fig. 1 the patients have been ranked according to the value of their initial $\mathrm{Fg}$ through the hemisphere at normocapnia. The changes in $\mathrm{Wg}$ were of the same order whether the Fg changed little from a low initial level (left side of graph), or greatly

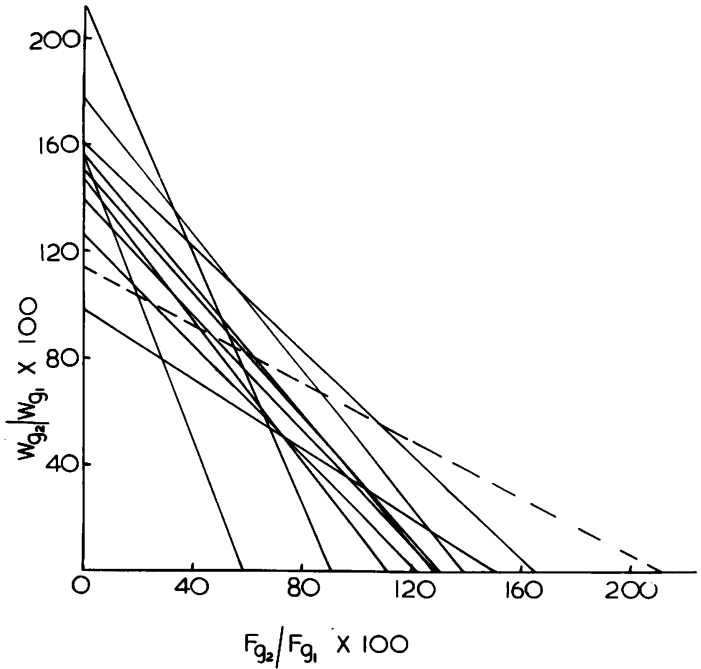

FIG. 2. Per cent change in $W g$ is plotted against per cent change in Fg for each area in the 11 patients. A line has been fitted to each plot and in 10 of the 11 patients (solid lines) there is a statistically significant negative correlation between per cent changes in Fg and $\mathrm{Wg}$. In the eleventh patient (dashed line) the correlation was not significant.

from a high initial level (right side of graph). The degree of change in blood flow was greatest in patients with a high initial flow-as has been previously shown by Olesen et al. (1971) and Ackerman et al. (1973) - but this did not affect the change in $\mathrm{Wg}$ which was of the same order in all the cases.

When the data were analysed on a regional instead of hemisphere basis it was found that in 10 of the 11 patients the $\mathrm{Wg}$ changed least in those areas where the $\mathrm{Fg}$ changed most and vice versa. The correlation coefficients between the regional values for change in $\mathrm{Fg}$ and change in $\mathrm{Wg}$ varied from -0.48 to -0.91 with significance levels ranging from better than 0.001 to 0.05 (Fig. 2). In the eleventh patient the correlation coefficient was -0.33 , which did not reach the conventional level of statistical significance.

\section{DISCUSSION}

The compartmental analysis of cerebral isotope clearance curves assumes that there are in the brain two distinct tissues clearing at significantly different rates; the fast clearing tissue has 
been identified with the grey matter and the slow clearing tissue with the white matter. The facts that isotope clearance curves from normal brain at normocapnia can be readily resolved into two compartments and that the proportion of fast and slow clearing tissue thus obtained correlates well with the proportion of grey and white matter found at anatomical dissection suggests that the assumption may be true for normal brain at normocapnia. The results of the present study show that it is not true when these conditions are altered. The proportion of fast clearing tissue in an area fell within a 15 minute period as the $\mathrm{PaCO}_{2}$ was lowered and the blood flow was reduced. Clearly, the amount of grey matter in the area could not have altered in that period of time.

When cerebral blood flow is markedly reduced, the resolution of isotope clearance curves into two well-defined components becomes difficult. The distinction between fast and slow clearing components is blurred, hence determination of the proportion of each must be to some extent arbitrary. This difficulty cannot, however, account entirely for the change in the proportion of fast clearing tissue found in this study as $\mathrm{PaCO}_{2}$ was lowered. The proportion of tissue clearing at fast rates was reduced. The amount of grey matter could not have decreased in the time, hence some of the grey matter must have been clearing at a much slower rate than it was initially.

Measurement of Wg by two-compartmental analysis of isotope clearance curves is not of an anatomical compartment, but of that proportion of brain tissue having a fast rate of blood flow. This fast flow compartment changes as the blood flow falls so that a smaller proportion of the brain is showing fast flow characteristics. The fast flow compartment is, therefore, a physiological rather than an anatomical entity.

The fact that those areas with highest blood flow and reactivity showed the least change in the proportion of tissue clearing at the fast rate is of interest. A possible explanation may be that the areas with a high blood flow represent areas with a high metabolic rate. In such areas of high neuronal activity it might be supposed that the total potential fast clearing compartment is working to its full capacity and that the vessels in these areas are more dilated in response to the assumed neuronal activity than vessels in less active areas. When the arterial $\mathrm{CO}_{2}$ tension is lowered, these regions will therefore have a high reactivity reflected by the considerable fall in flow. But if blood flow through only a small proportion of the fast flow compartment falls sufficiently to overlap with the slow component, there will be only a small reduction in the proportion of the fast flow compartment $(\mathrm{Wg})$. The reverse argument might apply in less active areas where at normocapnia blood flow is lower. For the same reduction in $\mathrm{PaCO}_{2}$, there will be a proportionately smaller fall in blood flow than $\mathbb{\mathbb { D }}$ in an active area, but, as less of the potentially fast clearing component was clearing at the fast rate, there will be a larger reduction in the proportion of the fast flow compartment $(\mathrm{Wg})$ than in active areas.

Our results indicate that the proportion of fast clearing tissue in the brain as measured by isotope clearance curves can change over so short $a$ period of time as to make it impossible to identif it with the anatomical proportion of grey matter? In these circumstances the conventional term weight grey $(\mathrm{Wg})$ might well be replaced by the term weight fast (Wf) as a more accurate expres sion of what is being measured.

The authors would like to thank Mrs Lynda Scott for technical assistance and Miss B. Laatz for preparation of the manuscript.

\section{REFERENCES}

Ackerman, R. H., Zilkha, E., Bull, J. W. D., Du Boulay, G. H., Marshall, J., Russell, R. W. R., and Symon, L. (1973). The relationship of the $\mathrm{CO}_{2}$ reactivity of cerebral ? vessels to blood pressure and mean resting blood flow. Neurology (Minneap.), 23, 21-26.

Høedt-Rasmussen, K., and Skinhøj, E. (1966). In vivo measurements of the relative weights of gray and white matter in the human brain. Neurology (Minneap.), 16, 515520.

Ingvar, D., Obrist, W., Chivian, E., Cronquist, S., Risberg, J., Gustafson, L., Hägerdal, M., and Wittbom-Cigén, G. o (1968). General and regional abnormalities of cerebral blood flow in senile and 'presenile' dementia. Scandinavian Journal of Clinical and Laboratory Investigation, 22, Suppl. 을 102, $12: \mathrm{B}$

Olesen, J., Paulson, O. B., and Lassen, N. A. (1971). Regional cerebral blood flow in man determined by the initial slope $N$ of the clearance of intra-arterially injected ${ }^{133} \mathrm{Xe}$. Stroke, N 2, 519-540.

Salmon, J. H., and Timperman, A. L. (1971). Cerebral blood 
flow in posttraumatic encephalopathy. The effect of ventriculoatrial shunt. Neurology (Minneap.), 21, 33-42.

Wilkinson, I. M. S., and Browne, D. R. G. (1970). The influence of anaesthesia and of arterial hypocapnia on regional blood flow in the normal human cerebral hemisphere. British Journal of Anaesthesia, 42, 472-482.
Wilkinson, I. M. S., Bull, J. W. D., Du Boulay, G. H., Marshall, J., Russell, R. W. R., and Symon, L. (1969). Regional blood flow in the normal cerebral hemisphere Journal of Neurology, Neurosurgery, and Psychiatry, 32, 367-378. 